\title{
S0530103
}

\section{テイラー・ディーン流れを利用したマイクロミキサの数值的研究 （混合に及ほすアスペクト比の影震）}

\author{
川邊 俊彦*1, 田原 功一郎 ${ }^{* 2}$, 早水 庸隆 ${ }^{* 3}$, 柳瀬 眞一郎 ${ }^{* 4}$, \\ 権田 岳 ${ }^{* 3}$, 森田 慎一 ${ }^{* 3}$, 大塚 茂 ${ }^{* 3}$, 山本 恭二*4

\section{Numerical Study of the Micromixer Using the Taylor-Dean Flow (Effect of Aspect Ratio on the Mixing)} \\ Toshihiko KAWABE ${ }^{* 1}$, Kouichiro TABARA ${ }^{* 2}$, Yasutaka HAYAMIZU ${ }^{* 3}$, Shinichiro YANASE ${ }^{* 4}$, \\ Takeshi GONDA $^{* 3}$, Shinichi MORITA*3, Shigeru OHTSUKA ${ }^{* 3}$, Kyoji YAMAMOTO ${ }^{* 4}$

\footnotetext{
${ }^{* 1}$ Tsurumi Manufacturing CO., LTD., 2700 Yomi-cho, Yonago-shi, Tottori 683-0851, Japan

${ }^{* 2}$ Advanced Course, Yonago National College of Technology, 4448 Hikona-cho, Yonago-shi, Tottori 683-8502, Japan

${ }^{* 3}$ Yonago National College of Technology, 4448 Hikona-cho, Yonago-shi, Tottori 683-8502, Japan

${ }^{*}$ Okayama University, 3-1-1 Tsushimanaka, Kita-ku, Okayama-shi, Okayama 700-8530, Japan
}

Chaotic mixing in a curved-rectangular channel flow is studied experimentally and numerically. Two walls of the channel (inner and top walls) rotate around the center of curvature and a pressure gradient is imposed in the direction toward the exit of the channel. This flow is a kind of Taylor-Dean flow. There are two parameters dominating the flow, the Dean number $\operatorname{De}(\propto$ the pressure gradient) and the Taylor number $\operatorname{Tr}(\propto$ the angular velocity of the wall rotation). In the present paper, we analyze the physical mechanism of chaotic mixing in the Taylor-Dean flow by comparing experimental and numerical results. It is found that good mixing performance is obtained in the case of $D e \leq 0.1 T r$. This tendency appears more strongly if aspect ratio is large.

Key Words : Micromixer, Taylor-Dean Flow, CFD

\section{1. 精}

近年, 化学やバイオなどの分野において $\mu$-TAS (Micro Total Analysis Systems) と呼ばれる超小型・化学分析装置 の開発が注目されている。この装置はさまざまなマイクロ流体素子やセンサなどからなり, 混合, 㩇拌, 反応, 分離や抽出などの一連の操作を行う. しかし，流路はマイクロサイズであるため，その流れは低レイノルズ数と

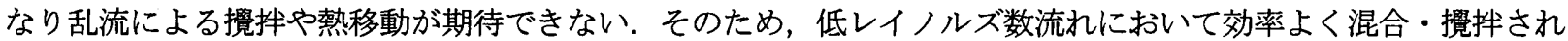
るマイクロ流体デバイスが必要とされている．そこで本研究では，曲がり管内流であるディーン流れと同軸回転 二重円筒内流であるテイラー流れを組み合わせたテイラー・ディーン流れ(1)を利用し，二次流れを複雑化させ， 混合·擅汼の促進を図るマイクロミキサの開発を目的とする.これまでの研究により二次流れの複雑化の影響で, 低レイノルズ数流れにおいても混合が促進されることが明らかにされている(2).

本講演では, 曲がり流路断面のアスペクト比の影響について，LIF 計測による実験と CFD による数值解析によ り検討した結果を報告する.

\footnotetext{
"1 正員，株式会社鶴見製作所（广683-8501 鳥取県米子市夜見町 2700）

${ }^{* 2}$ 学生員，米子工業高等専門学校専攻科（广683-8502 鳥取県米子市彦名町 4448）

"3 正員, 米子工業高等専門学校 (T683-8502 鳥取県米子市彦名町 4448)

$* 4$ 正員, 岡山大学 (下700-8530 岡山県岡山市北区津島中 3 丁目 1 番 1 号)

E-mail: hayamizu@yonago-k.ac.jp
} 


\section{2. 纪号および间这する实験式}

本研究で使用した曲がり流路の寸法を表 1 に示す. $2 a[\mathrm{~mm}]$ は流路幅, $2 b[\mathrm{~mm}]$ は流路高さ, $R[\mathrm{~mm}]$ は流路の曲 率半径, $\delta=a / R$ は流路の無次元曲率, $\gamma=b / a$ は流路断面のアスペクト比, $l[\mathrm{~mm}]$ は流路全長である.

Tablel Dimensions of curved channel

\begin{tabular}{|c|c|c|c|c|c|c|}
\hline Mixer & $2 a[\mathrm{~mm}]$ & $2 b[\mathrm{~mm}]$ & $R[\mathrm{~mm}]$ & $\delta$ & $\gamma$ & $I[\mathrm{~mm}]$ \\
\hline I & 3 & 3 & 15 & 0.1 & 1 & 58.9 \\
\hline II & 4.5 & 2 & 22.5 & 0.1 & 0.44 & 88.4 \\
\hline III & 2 & 4.5 & 10 & 0.1 & 2.25 & 39.3 \\
\hline
\end{tabular}

実験では，流路を流れる流量 $Q\left[\mathrm{~mm}^{3} / \mathrm{s}\right] ，$ ロータ角速度 $\Omega[\mathrm{rad} / \mathrm{s}]$ から，レイノルズ数 $R e=q d_{h} / v$ ，テイラー数(1) $\operatorname{Tr}=2(2 \delta){ }^{1 / 2} \Omega a^{2} /(\delta v)$ の無次元数を求めた. ここで, $q$ は流路内平均流速 $[\mathrm{mm} / \mathrm{s}], d_{h}=4 a b /(a+b)$ は水力直径 $[\mathrm{mm}]$, $v$ は作動流体の動粘度 $\left[\mathrm{mm}^{2} / \mathrm{s}\right]$ である. Tr は作動流体が流れる方向と同方向にロータを回転させる場合を正とする. また, 曲がり流路において $\delta$ の違いによる流量の違いを考慮するために曲がり流路層流パラメータであるディー ン数 ${ }^{(3)} \mathrm{De}=\operatorname{Re} \delta^{12}$ を用いた.

\section{3. 实験方法}

実験の手順としては，まず，図 1 のタンク (1)，(2)にそれぞれ試料である作動流体（グリセリン水溶液 $70 \mathrm{wt} \%$ と グリセリン水溶液 $70 \mathrm{wt} \%$ にレーザ蛍光染料であるローダミン B を濃度 $2.5 \mathrm{ppm}$ で溶解したもの）を溜め，ポンプ (3)，(4)によりオーバーフロータンク (5)，(6)一輸送する. 2 液は流路(7)で合流し，そのまま試験部である曲がり流 路(9)一と流れ込みバルブ(10で流量を調整し排水される. 流量は, 出口から流出する重量を測定し, 重量法により 算出した. 試験部のロータの駆動には, モータ88)用いた. 試験部の流路はロータとケーシングで形成しており, 流路の上壁面と内壁がロータである (図 2 参照). (11は可視化の際に光の屈折を緩和し二次流れを見やすくするた めの水で満たしたビューイングブロックである.

可視化方法は図 2 のように, 流路側面を波長 532nm の CW レーザシート (LaVision 社:CW-532-3W) で照らし, 流路断面をハイスピードカメラ（LaVision 社 : HSS4G）で撮影した．撮影位置は図 2 のように曲がり流路入口か ら $180^{\circ}$ の位置で行った. また, LIF 計測を行うために，ハイパスフィルタ（透過波長 $570 \mathrm{~nm}$ 以上）をつけローダ ミン B の蛍光のみを取得し, 得られた画像を Davis 8 （LaVision 社）により解析することで濃度分布を算出した.

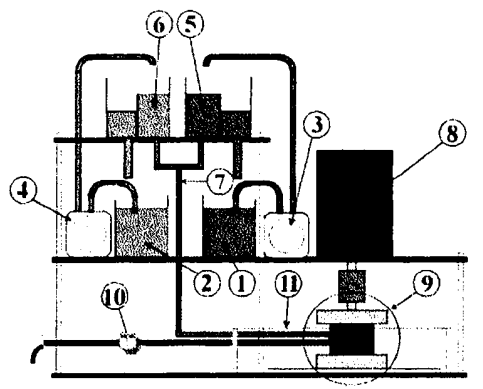

Fig.1 Experimental setup

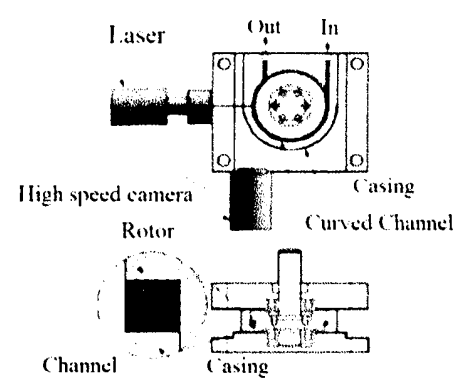

Fig.2 Method of visualization

\section{4. 数什解析方法および解析条件}

CFD には，有限体積法に基づくオープンソースコードである OpenFOAM（version 2.0.1）を用いた. ソルバー は 3 次元非圧縮非定常, 層流の速度一圧カソルバーである icoFoamにより流れ場を計算し, パッシブスカラの輸 送方程式を解くソルバーの scalarTransportFoam を用いて icoFoam により計算された流れ場を基に混合状態の計算 を行った. 
計算格子は OpenFOAM で提供されるメッシュ・ジェネレータ blockMeshにて作成した．格子形状は，図 3 (a) に示すように実験装置の流路部分のみを取り出したものとなっており，格子は曲がり流路断面方向に 40×40配置 し，全格子数は 185880 個となっている.

境界条件として，入口に各 Deに応じた一様流速の流入を，出口には圧力 $0 \mathrm{~Pa}$ を与えている．また，ロータの 回転による壁面の移動は，回転壁面として $\operatorname{Tr}$ に応じた角速度 $\Omega$ を与えた（図 3(b)中の赤色で示した壁面)．さら に, 混合状態の計算の際には, 初期条件として全体の濃度 $0 \%$ から始め, 流路の内側に濃度 $100 \%$ の流体を, 外側 に濃度 $0 \%$ の流体を流路入口より流入させた．そして，濃度の分布が十分安定するまで計算を行った。

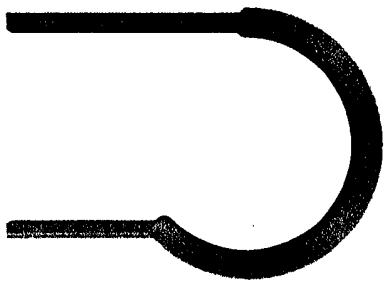

(a) Computational grid

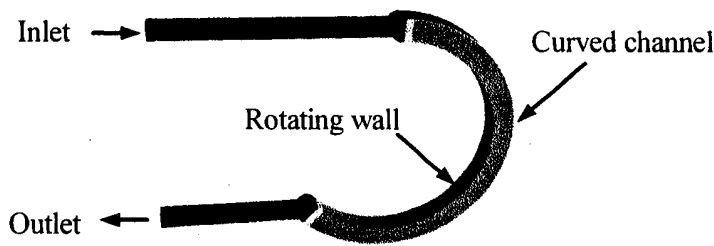

(b) Boundary condition

Fig.3 Model of computation of curved channel

\section{5. 結果および孝察}

図 4 に Mixer I, Mixer II, Mixer III の曲がり流路入口から 180 度の断面における LIF 結果を示す. (a)が Mixer I, (b)が Mixer II, (c)が Mixer III のローダミンB を溶解したグリセリン水溶液濃度の等值線図を示したものである. 各図の右横のカラーバーはローダミン B で染色されたグリセリン水溶液の濃度を示しており, 濃度 $50 \%$ 付近の領 域が増加することにより，混合が促進されていると評価する. 各図の右端と上端がロー夕壁面，左端と下端がケ ーシング壁面である. また, 画像は上流側から見た時のもので, 2 液は左右でロータ側にローダミン $\mathrm{B}$ を溶解し たグリセリン水溶液が来るよう 2 液を同量で 2 層となるよう流した.

まず(a)の Mixer I の結果を見てみると，未混合領域があるものの広い範囲で良好な混合が得られている．他の $D e$ と $T r$ でも実験した結果，良好な混合が得られる条件は，De $\leq 0.1 T r$ の関係であることが分かった．次に(b)の Mixer II の結果を見てみると，未混合領域が広く良好な混合が得られていない，一方，(c)の Mixer III の場合は， 3 つの Mixerのうちで最も混合領域が広く，良好な混合が得られている.このことより，アスペクト比が大きく なると混合が促進されると考えられる.

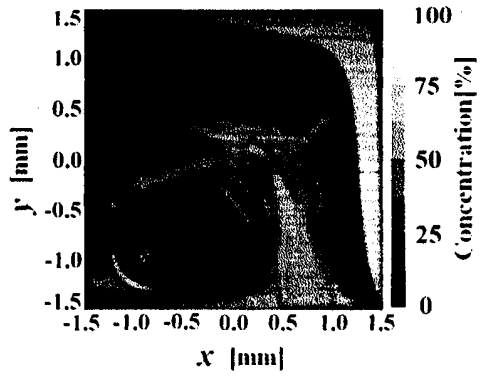

(a) Mixer I

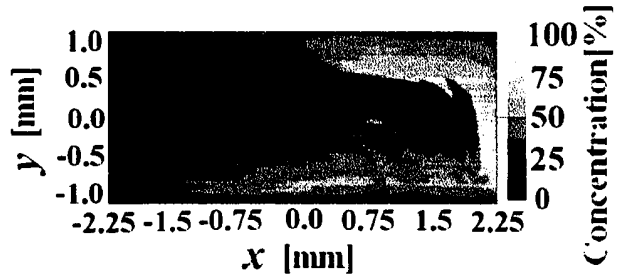

(b) Mixer Il

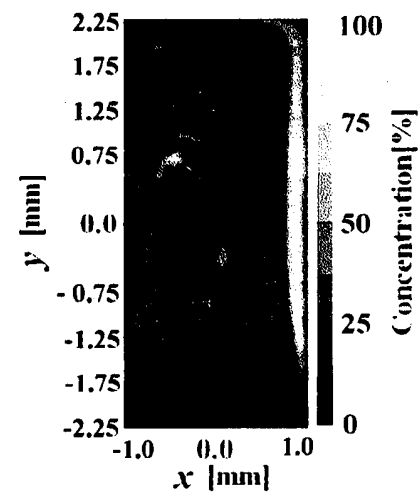

(c) Mixer III

Fig. 4 Flow pattern of LIF at $T r=3$ and $D e=0.3$ 
図 5 は Mixer I の図 4(a)と同条件での CFD 結果を示したものである.(a)がローダミン B を溶解したグリセリン 水溶液濃度の等値線図, (b)が軸流速度の等値線図, (c)が二次流れ速度のベクトル線図である.

(a)の濃度分布は LIF 結果と同様，広い範囲で良好な混合が得られており，分布形状も LIF 結果と近いことが分 かる. 次に(b)の軸流速度より，混合がなされている部分には逆流が発生していることが分かる. この逆流が発生 する原因としては，ロータの回転によって出口付近の圧力が上昇し，逆圧力勾配が発生することによるものだと 考えられる. また，ロータ壁面である上端，右端付近はロータの回転の影響が支配的であるため，逆流が発生し ていない. (c)の二次流れを見てみると, 全体的にはロータからケーシングへと向かう流れであるが，3 つの渦も 確認でき，ロータ壁面付近の上端に 1 渦，(b)の逆流が発生した部分に 2 渦が発生している.この 3 つ渦は, 図 4(a)の LIF 結果においても確認できる.

以上の結果から, 本数值解析は実際の現象を十分に表せており, 妥当な解析ができているものと判断でき る. 今後さらにこの解析結果を用いて混合に及ぼす曲がり流路断面のアスペクト比の影響を調査する.

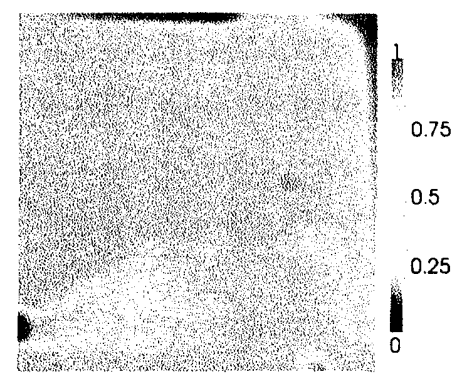

(a) Concentration

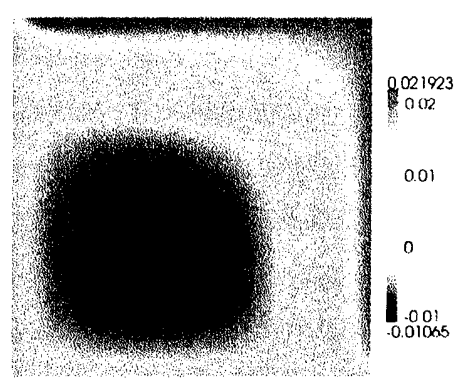

(b) Axial Flow

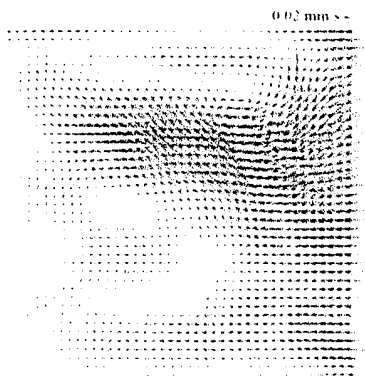

(c) Secondary Flow

Fig. 5 Flow pattern of CFD at $T r=3$ and $D e=0.3$ (Mixer I)

\section{文嗝}

(1) K. Yamamoto, X. Wu, K. Nozaki and Y. Hayamizu, "Visualization of Taylor-Dean flow in a curved duct of square cross-section", Fluid Dynamics Research, Vol.38, (2006), PP.1-18.

(2) Y. Hayamizu, S. Yanase, S. Morita, S. Ohtsuka, K. Nishida, T. Gonda and K. Yamamoto, "A Micromixer Using the Chaos of Secondary Flow: Rotation Effect of Channel on the Chaos of Secondary Flow", Open Journal of Fluid Dynamics, Vol. 2, No. 4A (2012), PP.195-201.

（3）日本機械学会編，技術資料流路・ダクトの流体抵抗，(1979), pp.68-71, 日本機械学会. 